\title{
Effect of heat and chemical preservatives on the overall quality of Muskmelon cubes preserved in sucrose solution
}

\author{
Haris Bilal ${ }^{*}$, Yasser Durrani ${ }^{1}$, Majid Suhail Hashmi ${ }^{1}$,Ali Muhammad ${ }^{1}$, \\ Muhammad Noor uddin ${ }^{1}$, Qaiser Ali Sultan ${ }^{1}$ and Mukhtar Ud Din ${ }^{2}$ \\ 1. Department of Food Science and Technology,The University of Agriculture Peshawar-Pakistan \\ 2. Department of Human Nutrition, The University of Agriculture Peshawar-Pakistan \\ *Corresponding author's email: HarisBilal70@gmail.com \\ Citation \\ Haris Bilal, Yasser Durrani, Majid Suhail Hashmi, Ali Muhammad, Muhammad Noor uddin, Qaiser Ali Sultan and \\ Mukhtar Ud Din. Effect of heat and chemical preservatives on the overall quality of Muskmelon cubes preserved in \\ sucrose solution. Pure and Applied Biology. Vol. 8, Issue 2, pp1016-1024. \\ http://dx.doi.org/10.19045/bspab.2019.80042
}

\begin{tabular}{llll}
\hline \hline Received: 11/12/2018 & Revised: 12/03/2019 & Accepted: 28/03/2019 & Online First: 03/04/2019 \\
\hline \hline
\end{tabular}

\section{Abstract}

This research was conducted to examine sucrose solution effect with selected food chemical preservatives potassium metabisulfite (PMS) and potassium sorbate (PS) on overall quality of the muskmelon cubes in sealed plastic jars and kept at ambient temperature.The importance of this study was to inhance the storage life of muskmelon fruit because alot of muskmelon goes surplus during the peak season. These treatments were analyzed physico-chemically $(\mathrm{pH}$, titratable acidity, ascorbic acid, TSS, reducing sugar and non-reducing sugar) and organoleptically (texture, color, flavor and overall acceptability) at 15 days of interval for 90 days. Storage results showed that decreased was found in $\mathrm{pH}(6.10$ to 5.43$)$, ascorbic acid (35.18 to $18.39 \mathrm{mg} / 100 \mathrm{~g}$ ) and nonreducing sugar (14.04 to $11.95 \%)$. Similarly decrease in score rate was found for overall acceptability ( 8.20 to 7.60$)$. An increase was found in muskmelon cubes for titratable acidity ( 0.08 to $0.14 \%$ ), TSS ( 18.40 to $22.54^{\circ}$ Brix) and reducing sugar (4.23 to $5.84 \%$ ) during three months of storage. Statistical results revealed that treatment $\mathrm{T}_{5}$ was found the best for overall quality (texture, color, flavor and nutritive stability) of muskmelon cubes preserved in sucrose solution and treated with chemical food preservatives followed by $T_{2}, T_{7}, T_{4}, T_{6}$ and $T_{3}$ respectively for all aspects.

Keywords: Chemical preservatives; Muskmelon cubes; Sucrose solution; Sensory analysis

\section{Introduction}

The economy of Pakistan is mostly dependent on the agriculture sector. This country climatic environment is also most suitable for the cultivation of various kinds of fruits and vegetables. Several kinds of wellknown vegetables and fruits are grown here in the four seasons of the year [1]. Due to the awareness in the public about the nutritional importance of fruits in their diet, the demand for the fruits and their processed fruits products is gradually increasing. One of these fruits which are abundantly grown in the province of KPK is muskmelon. Various types of muskmelon are grown which are different in color and taste depend on its variety and climatic conditions of the area where it had been grown. Muskmelon relates to Cucurbitaceous family and Cucumuis (muskmelon) is known as sweet melon [2]. 
Muskmelom is one of the more consumed fruit in the world [3]. In Pakistan the total area under cultivation for muskmelon is 48319 hectare with a productionrate 723868 tones (F/V and condiments statistic of Pakistan, [4].

[5] Reported that maillard browning of glycine-glucose reaction $(\mathrm{pH} 5.5)$ was increased with sorbic acid. Acid-base catalysis is also involved in some browning. In food maillard bowning is also controlled by sulphur dioxide and it salts it's a good way or strategy to control it.[6] Found that browning due to proteins-glucose as well as sorbic acid was reduced up to $30 \%$. To inhibit non enzymatic browning $\mathrm{SO}_{2}$ can be used, enzyme catalyzed reactions can be inhibited, microorganisms can be controlled and it can also act as an antioxidant and reducing agent [7]. Sorbic acid E200 is a straight chain $\alpha, \beta$ unsaturated trans-trans 2, 4-hexadienoic monocarboxylic aliphatic acid and has the molecular formula $\mathrm{CH}_{3}-\mathrm{CH}=\mathrm{CH}-\mathrm{CH}=\mathrm{CH}-$ $\mathrm{COOH}\left(\mathrm{C}_{6} \mathrm{H}_{8} \mathrm{O}_{6}\right)$. In water at $25^{\circ} \mathrm{C}$ the solubility of sorbic acid is $0.16 \%$ and of potassium sorbate over $50 \%$. Solubility in water increases with $\mathrm{pH}$ and temperature. Increased concentrations more than $10 \%$ of emulsified food items with glucose, sucrose, and sodium chloride reduce the sorbates solubility in water. Enzymes are complicated organic compounds which play a role as catalyst which make the synthetical changes. Different microorganisms are also bringing spoilage of foods. They can be controlled by heat and antimicrobials additives [8].Due to lack of proper preservation facilities and poor market system in our country large quantity of our fruits especially muskmelon fruit abundantly grown in KPK is wasted and ultimately a big income losses to farmers as well as to our national economy [9]. Muskmelon fruit is abundantly grown in the KPK province of Pakistan. In the peak season the surplus product of muskmelon is sold at cheaper rates because the growers are afraid that their product will be wasted due to costly and limited cold storages and other preservation facilities in the province. In this research proposal the muskmelon cubes were preserved in sucrose solution and treated with selected chemical preservatives.

\section{Materials and methods}

Fresh and good quality of muskmelon fruit (Honey-Dew variety) was selected for this study. The required quantity of muskmelon was purchased from Peshawar fruit market and used for the research treatments. The research work was conducted in the Department of Food Science \& Technology, Faculty of Nutrition Sciences, The University of Agriculture Peshawar.

\section{Washing}

The muskmelons were properly washed with pressurized tap water to remove dust, insecticides, pesticides and other extraneous materials present on the muskmelon. After washing the healthy, defect free and matured sweetened muskmelons were selected for the preparation of research treatments.

\section{Preparation of muskmelon cubes}

Muskmelons were cut vertically in four pieces (from top to bottom). After coring the cut pieces were then peeled with the help of stainless steel knife. The muskmelon pieces were transferred to a stainless steel kettle which containing sterilized cool tap water containing $0.2 \%$ citric acid. The pieces were dipped in the solution so to prevent nonenzymatic browning due to oxidation. The muskmelon was then cut in uniform cube shaped in square inch pieces. Blanching of the required amount of muskmelon cubes for the number of treatments was carried out in water at boiling temperature for 4 to 5 minutes to inactivate the enzymes of catalase and peroxidase which are responsible for enzymatic browning of the fruit.

\section{Proposed plan of the research}

The treatments samples were packed in transparent plastic jars containing sucrose solution $30^{\circ}$ brix and then properly closed 
with jars caps. The samples were stored at ambient temperature.

To: Unblanched Muskmelon cubes $+30^{0}$ brix Sucrose solution.

T1: Blanched Muskmelon cubes $+30^{0}$ brix Sucrose solution.

T2: Unblanched Muskmelon cubes +Sucrose solution $30^{\circ}$ brix $+0.1 \%$ Potassium metabisulphite

T3: Unblanched Muskmelon cubes + Sucrose solution $30^{\circ}$ brix $+0.1 \%$ potassium sorbate

T4: Unblanched Muskmelon cubes +Sucrose solution $30^{\circ}$ brix $+0.05 \%$ Potassium metabisulphite $+0.05 \%$ potassium sorbate T5: Blanched Muskmelon cubes +Sucrose solution $30^{\circ}$ brix $+0.1 \%$ Potassium metabisulphite

T6: Blanched Muskmelon cubes +Sucrose solution $30^{\circ}$ brix $+0.1 \%$ potassium sorbate

T7: Blanched Muskmelon cubes +Sucrose $30^{0}$ brix $+0.05 \%$ Potassium metabisulphite $+0.05 \%$ potassium sorbate

\section{Physicochemical analysis}

The jars were sealed and stored at room temperature for shelf life study and overall quality evaluation of muskmelon cubes. The storage effect on physicochemical criterion ( $\mathrm{pH}$, TSS, acidity ascorbic acid, nonreducing sugars and reducing sugars) were analyzed by Lane and Eynon method [10].

\section{Sensory evaluation}

The samples of muskmelon cubes preserved in sucrose solution were sensory calculated for texture, color, flavor and over all acceptability by the panel of 10 judges. Organoleptic study was carried out for each 15days interval for 90 days of storage. The evaluation was conducted by using9 point hedonic scale of [11].

\section{Statistical analysis}

All the data including storage and treatments intervals was statistically calculated by means of completely Randomized Design (CRD) 2 Factorial as endorsed by [12] and means was separated by applying (LSD) Test at 5\% possibility level as defined by Steel and Torrie [13].

\section{Results and discussion Physicochemical analysis}

The statistical result showed that storage interval and treatments has a significant $(\mathrm{P}<$ 0.05 ) effect over $\mathrm{pH}$ value of muskmelon cubes in the entire three months of storage. (Table1).The mean values for $\mathrm{pH}$ were significantly $(\mathrm{P}<0.05)$ decreased from $\mathrm{pH}$ 6.10 to 5.43 during ninety days of storing period. High mean values was noticed at treatment $\mathrm{T}_{5}(6.04)$ and the lesser mean value was found $\mathrm{T}_{0}$ (4.73). Similarly [14] during osmotic de-hydration and re-hydration attributes of pineapple slices a decrease was noticed in $\mathrm{pH}$ values.

The results acknowledged by statistics are that storage interval and treatments had a significantly $(\mathrm{P}<0.05)$ effected on the percent-acidity of the muskmelon cubes preserved in sucrose solution. The mean values of $\%$ acidity significantly $(\mathrm{P}<0.05)$ increased from $0.08 \%$ to $0.14 \%$. High mean values were observed for treatment $\mathrm{T}_{0}(0.14)$ while the lowest mean value was observed in treatments $\mathrm{T}_{2}, \quad \mathrm{~T}_{5}, \mathrm{~T}_{7}$ and $(0.08) \quad \mathrm{T}_{0}$ respectively. Maximum increase was found in $\mathrm{T}_{0}(63.14 \%)$ and minimum in $\mathrm{T}_{2}, \mathrm{~T}_{5}$ and $\mathrm{T}_{7}$ (22.22\%)as shown in (Table 2).Same results were considered by [15] in osmotically vacuumed dried mango slice.

The statistical results showed storage interval and treatments had a significant $(\mathrm{P}<0.05)$ influence on the total soluble solids of the muskmelon cubes preserved in sucrose solution and stored for three months at ambient temperature (Table3). The mean values of TSS significantly $(\mathrm{P}<0.05)$ increased from 18.40 to 22.54 degree brix. High average mean values of TSS degree brix were observed in treatment $\mathrm{T}_{5}(21.27)$ while the lowest average mean value of degree brix was found in treatment $T_{0}$ (19.76) respectively. The maximum percent increase in TSS was found in $\mathrm{T}_{0}(23.28 \%)$ and 
minimum in $\mathrm{T}_{0}(8.42 \%)$ respectively as shown in (Table 3).Same results were observed [15] of vacuumed de hydrated mango slices. In mandarin's slices a boost in solids soluble content was noticed [16].Our results are also in consolidation with [17] who found the boost in TSS of apple pulp conserved with food additives during storage. The statistical results revealed that storage interval and treatments significantly $(\mathrm{P}<$ 0.05) influenced ascorbic acid reduction of muskmelon cubes stored at ambient temperature (Table 4). The mean values of ascorbic acid content were significantly $(\mathrm{P}<$ 0.05 ) decreased from 35.18 to $18.39 \mathrm{mg} / 100 \mathrm{~g}$ during storage. Highest average mean value for treatment was found in $T_{2}$ $(30.58 \mathrm{mg} / 100 \mathrm{~g})$ while lowest mean value was found in $\mathrm{T}_{0}(25.87 \mathrm{mg} / 100 \mathrm{~g})$. Low decrease was observed in $\mathrm{T}_{6}(38.91 \%)$ while maximum percent decrease was found in $\mathrm{T}_{0}$ $(67.12 \%)$ as shown in (Table 4). [18] Reported regarding the preservation of apple juice with selected chemical preservatives and found the decline in vit-c in storage at ambient temperature.

The results acknowledged by statistics are that treatments and storage interval has a significant $(\mathrm{P}<0.05)$ effect on reducing sugar of muskmelon cubes during three months of storage. (Table 5).The mean values of the treatment for reducing sugar significantly $(\mathrm{P}<$ 0.05 ) inclined from 4.23 to $5.84 \%$ in three months of cache period. High average mean value for treatment was determined in $\mathrm{T}_{4}$ $\operatorname{andT}_{7}(5.26 \%)$ while lowest mean value for treatment was observed $\mathrm{T}_{3} \quad(4.7 \%)$ respectively. Maximum increase at three months storage as compared to initial amount reducing sugar of muskmelon cubes was found in $\mathrm{T}_{7}(34.06 \%)$ while minimum increased in treatment $\mathrm{T}_{0}$ (14.29\%)respectively as shown in (Table 5).[19] Studied juice products which were treated with various chemical additives and sucrose additive. [16] Also show same result in pine apple slices osmo-dehydration.

The results acknowledged by statistics are that storage interval and treatments had a significant $(\mathrm{P}<0.05)$ effect on non-reducing sugar of the muskmelon cubes during storage (Table 6).The mean values for non-reducing sugars was significantly $(\mathrm{P}<0.05)$ decreased from $14.04 \%$ to $121.95 \%$ during storage. The highest mean value was noticed in $\mathrm{T}_{5}$ (13.52) while minimum mean value was noticed in $\mathrm{T}_{1}$ (12.80). Maximum percent-reduction in nonreducing take place in $\mathrm{T}_{0}(21.68 \%)$ while minimum in $\mathrm{T}_{7}(8.5)$ as shown in (Table 6). [20] Noticed same decrease in non-reducing sugar of sucrose to glucose and fructose used for muskmelon cubes preservation. [19] Found as same results for juice preservation treated with chemical-preservatives.

\section{Organoleptic evaluation of muskmelon cubes}

The sensory analysis taken place with the help of Larmond scale (hedonic 9 points) through 15 trained judges' panel they have experience for testing food samples through organoleptically evaluation.

The results that are acknowledged by the statistics is that repository interval and treatments has a significant $(\mathrm{P}<0.05)$ effect on muskmelon cubes during repository and on its overall acceptability (got by color, flavor and texture) of Muskmelon Cubes(Table 7).The mean values of muskmelon cubes were significantly $(\mathrm{P}<$ $0.05)$ decreased from 7.85 to 6.30 during three months of repository. The maximum mean value of muskmelon cubes for overall acceptability was found in $\mathrm{T}_{7}$ (7.86) while minimum in $\mathrm{T}_{0}(5.43)$ as shown in (Table 7). These results are supported by [21] who notices decrease on the overall acceptability of osmo-dehydrated slices of mangoes with inverted sugar sucrose and syrups. The conclusion is interlinked with [22] over all acceptability was reduced in apple slice. 
Table 1. Effect of selected chemical preservatives on pH of muskmelon cubes preserved in sucrose solution and stored at ambient temperature

\begin{tabular}{|c|c|c|c|c|c|c|c|c|c|c|}
\hline \multirow{2}{*}{ Treat } & \multicolumn{7}{|c|}{ Storage Interval } & \multirow{2}{*}{\multicolumn{2}{|c|}{$\%$ Dec }} & \multirow{2}{*}{ Mean } \\
\hline & initial & 15 & 30 & 45 & 60 & 75 & 90 & & & \\
\hline \multicolumn{11}{|c|}{ pH of Muskmelon Cubes } \\
\hline $\mathbf{T}_{\mathbf{0}}$ & 6.02 & 5.82 & 5.45 & 5.42 & 5.04 & 4.81 & 4.73 & 21.43 & 5.3 & $3 c \pm 0.49$ \\
\hline $\mathbf{T}_{1}$ & 6.05 & 6.0 & 6.0 & 5.30 & 4.88 & 4.90 & 4.82 & 20.33 & & $4 c \pm 0.57$ \\
\hline $\mathbf{T}_{2}$ & 6.15 & 6.10 & 6.08 & 6.01 & 5.95 & 5.85 & 5.75 & 7.32 & 5.9 & $8 a \pm 0.15$ \\
\hline $\mathbf{T}_{3}$ & 6.08 & 6.00 & 5.90 & 5.72 & 5.45 & 5.30 & 5.11 & 12.71 & 5.7 & $2 \mathrm{~b} \pm 0.28$ \\
\hline $\mathbf{T}_{4}$ & 6.16 & 6.08 & 6.05 & 6.00 & 5.92 & 5.88 & 5.78 & 7.31 & 5.9 & $7 a \pm 0.14$ \\
\hline $\mathbf{T}_{5}$ & 6.14 & 6.14 & 6.11 & 6.06 & 6.05 & 5.96 & 5.85 & 5.54 & 6.0 & $4 a \pm 0.12$ \\
\hline$T_{6}$ & 6.10 & 6.05 & 6.00 & 5.82 & 5.65 & 5.53 & 5.44 & 8.36 & 5.8 & $5 \mathrm{ab} \pm 0.20$ \\
\hline $\mathbf{T}_{7}$ & 6.11 & 6.10 & 6.08 & 6.00 & 5.92 & 5.88 & 5.78 & 5.40 & 5.9 & $8 a \pm 0.12$ \\
\hline Mean & $\begin{array}{c}6.10 \mathrm{a} \pm \\
0.05\end{array}$ & $\begin{array}{c}6.04 \mathrm{a} \pm \\
0.10\end{array}$ & $\begin{array}{c}5.96 \mathrm{ab} \pm \\
0.21\end{array}$ & $\begin{array}{c}5.79 b c \pm \\
0.29\end{array}$ & $\begin{array}{c}5.65 \mathrm{~cd} \pm \\
0.44\end{array}$ & $\begin{array}{c}5.55 \mathrm{de} \pm \\
0.45\end{array}$ & $\begin{array}{c}5.43 \mathrm{e} \pm \\
0.43\end{array}$ & & & \\
\hline
\end{tabular}

Values having different alphabetical letters are significantly $(\mathrm{P}<0.05)$ different

Table 2. Effect of selected chemical preservatives on Titratable Acidity of muskmelon cubes preserved in sucrose solution and stored at ambient temperature

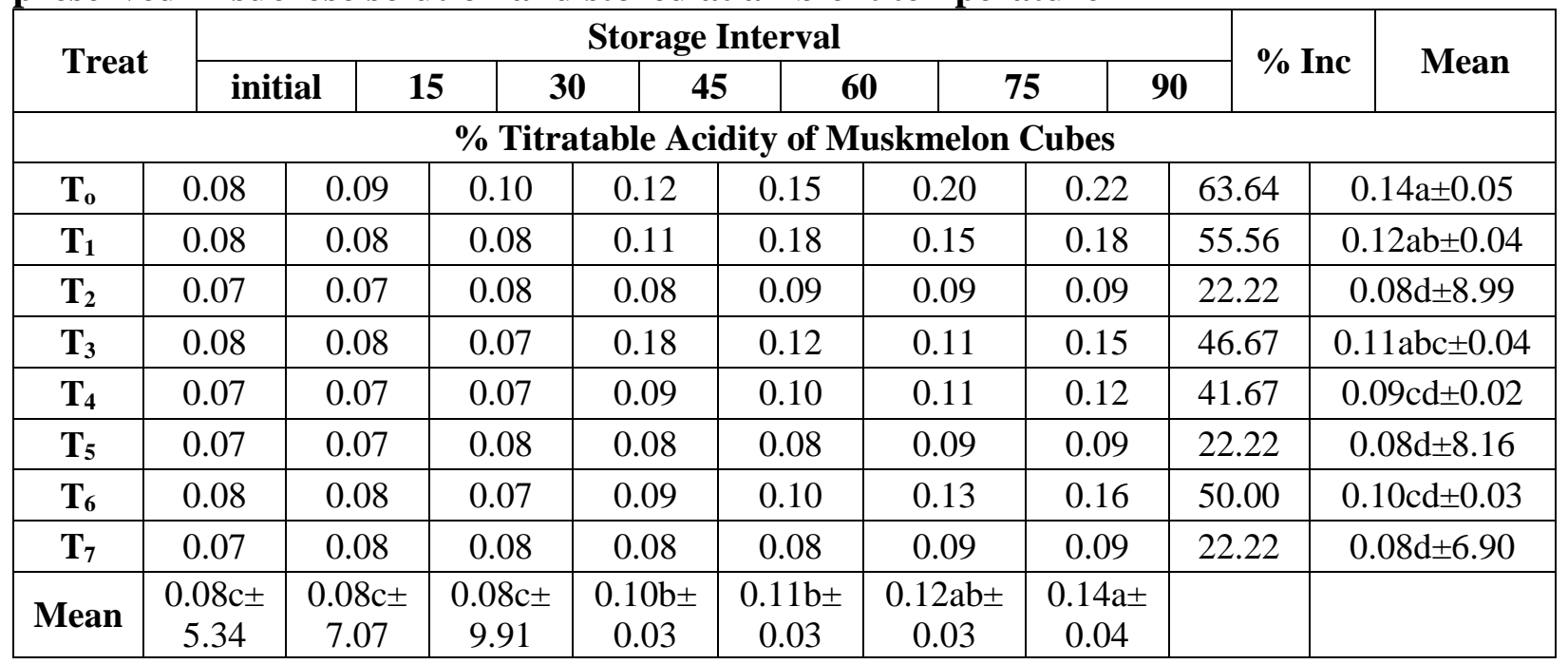

Values having different alphabetical letters are significantly $(\mathrm{P}<0.05)$ different 
Bilal et al.

Table 3. Effect of selected chemical preservatives on TSS ( $\left.{ }^{\circ} \mathrm{Brix}\right)$ of muskmelon cubes preserved in sucrose solution and stored at ambient temperature

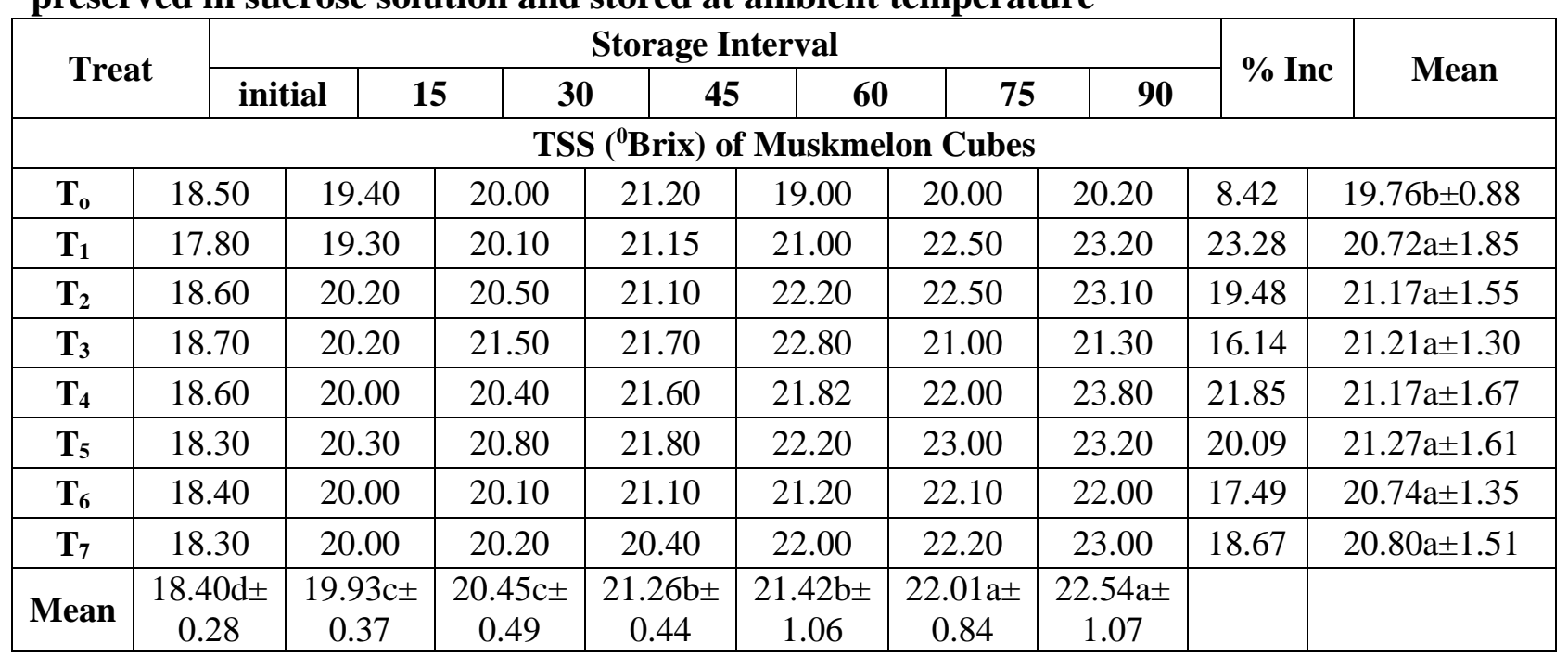

Values having different alphabetical letters are significantly $(\mathrm{P}<0.05)$ different

Table 4. Effect of selected of chemical preservatives on Ascorbic Acid (mg/100g) of muskmelon cubes preserved in sucrose solution and stored at ambient temperature

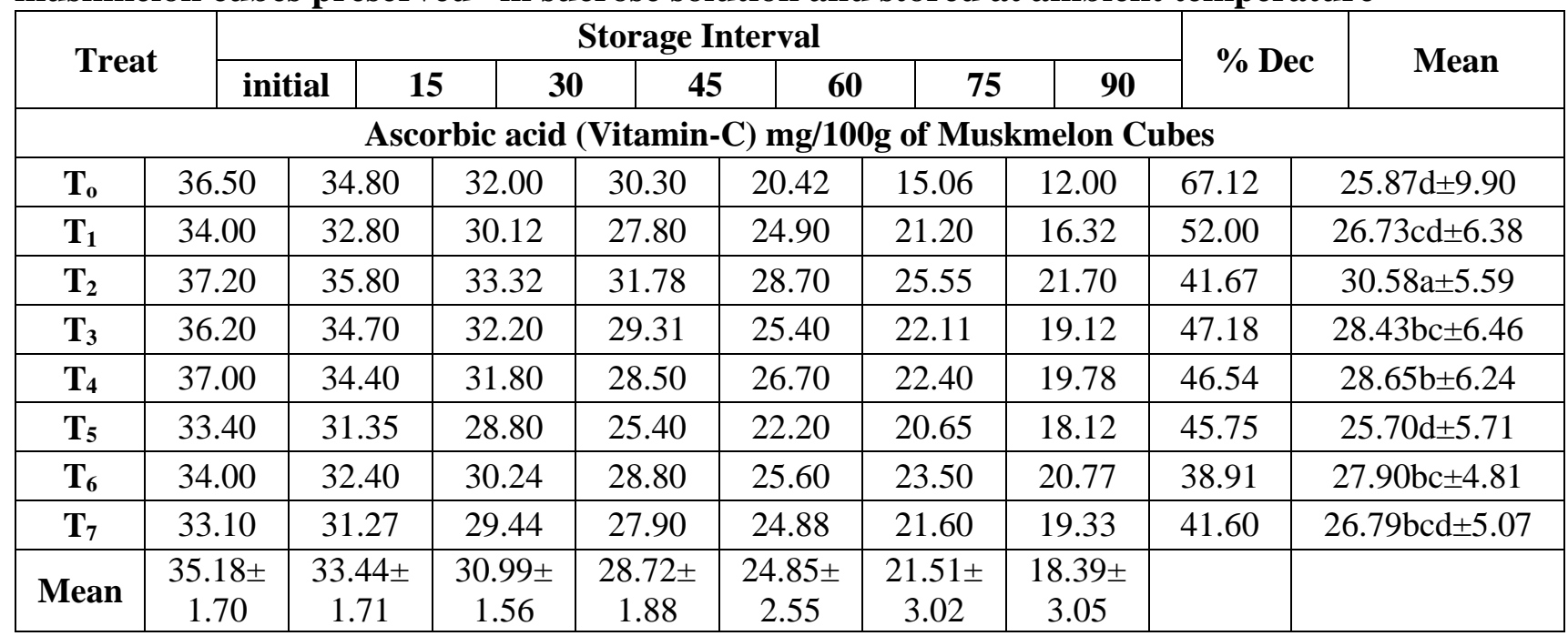

Values having different alphabetical letters are significantly $(\mathrm{P}<0.05)$ different 
Table 5. Effect of selected chemical preservatives on Reducing Sugar (\%) of muskmelon cubes preserved in sucrose solution and stored at ambient temperature

\begin{tabular}{|c|c|c|c|c|c|c|c|c|c|c|c|}
\hline \multirow{2}{*}{ Treat } & \multicolumn{7}{|c|}{ Storage Interval } & \multirow{2}{*}{ \% Inc } & \multirow{2}{*}{ Mean } \\
\cline { 2 - 11 } & initial & $\mathbf{1 5}$ & $\mathbf{3 0}$ & $\mathbf{4 5}$ & $\mathbf{6 0}$ & $\mathbf{7 5}$ & $\mathbf{9 0}$ & & \\
\hline \multicolumn{8}{|c|}{ Reducing sugar (\%) of Muskmelon Cubes } \\
\hline $\mathbf{T}_{\mathbf{0}}$ & 4.20 & 4.50 & 5.20 & 5.80 & 5.40 & 5.30 & 4.90 & 14.29 & $5.04 \mathrm{abc} \pm 0.75$ \\
\hline $\mathbf{T}_{\mathbf{1}}$ & 4.10 & 4.51 & 4.70 & 4.88 & 5.06 & 5.13 & 5.88 & 30.27 & $4.89 \mathrm{c} \pm 0.75$ \\
\hline $\mathbf{T}_{\mathbf{2}}$ & 4.30 & 4.51 & 4.78 & 4.88 & 5.05 & 5.50 & 6.10 & 29.51 & $5.04 \mathrm{abc} \pm 0.75$ \\
\hline $\mathbf{T}_{\mathbf{3}}$ & 4.25 & 4.10 & 4.67 & 4.86 & 5.12 & 5.23 & 5.12 & 16.99 & $4.76 \mathrm{c} \pm 0.75$ \\
\hline $\mathbf{T}_{\mathbf{4}}$ & 4.18 & 4.52 & 4.86 & 5.34 & 5.80 & 5.95 & 6.20 & 32.58 & $5.26 \mathrm{a} \pm 0.75$ \\
\hline $\mathbf{T}_{\mathbf{5}}$ & 4.35 & 4.30 & 4.82 & 5.12 & 5.55 & 5.90 & 6.30 & 30.95 & $5.19 \mathrm{ab} \pm 0.75$ \\
\hline $\mathbf{T}_{\mathbf{6}}$ & 4.23 & 4.11 & 4.61 & 4.90 & 5.15 & 5.65 & 5.80 & 27.07 & $4.92 \mathrm{bc} \pm 0.75$ \\
\hline $\mathbf{T}_{\mathbf{7}}$ & 4.22 & 4.60 & 4.96 & 5.20 & 5.53 & 5.90 & 6.40 & 34.06 & $5.26 \mathrm{a} \pm 0.75$ \\
\hline \multirow{2}{*}{$\mathbf{M e a n}^{2}$} & $4.23 \mathrm{e} \pm$ & $4.39 \mathrm{e} \pm$ & $4.83 \mathrm{~d} \pm$ & $5.12 \mathrm{c} \pm$ & $5.33 \mathrm{c} \pm$ & $5.57 \mathrm{ab} \pm$ & $5.84 \mathrm{a} \pm$ & & \\
& 0.26 & 0.25 & 0.26 & 0.25 & 0.26 & 0.25 & 0.26 & & \\
\hline
\end{tabular}

Values having different alphabetical letters are significantly $(\mathrm{P}<0.05)$ different

Table 6. Effect of selected chemical preservatives on Non-Reducing Sugar (\%) of muskmelon cubes preserved in sucrose solution and stored at ambient temperature

\begin{tabular}{|c|c|c|c|c|c|c|c|c|c|c|c|}
\hline \multirow{2}{*}{ Treat } & \multicolumn{7}{|c|}{ Storage Interval } & \multirow{2}{*}{ \% Dec } & \multirow{2}{*}{ Mean } \\
\cline { 2 - 11 } & initial & $\mathbf{1 5}$ & $\mathbf{3 0}$ & $\mathbf{4 5}$ & $\mathbf{6 0}$ & $\mathbf{7 5}$ & $\mathbf{9 0}$ & & \\
\hline \multicolumn{8}{|c|}{ Non-Reducing sugar $(\mathbf{\%})$ of Muskmelon Cubes } \\
\hline $\mathbf{T}_{\mathbf{0}}$ & 14.30 & 14.00 & 13.80 & 13.50 & 13.00 & 12.35 & 11.20 & 21.68 & $13.16 \mathrm{~b} \pm 0.75$ \\
\hline $\mathbf{T}_{\mathbf{1}}$ & 13.75 & 13.72 & 13.60 & 13.20 & 12.50 & 11.50 & 11.00 & 20.00 & $12.80 \mathrm{~d} \pm 0.75$ \\
\hline $\mathbf{T}_{\mathbf{2}}$ & 14.30 & 14.01 & 14.00 & 13.45 & 13.05 & 12.60 & 12.13 & 15.17 & $13.36 \mathrm{a} \pm 0.75$ \\
\hline $\mathbf{T}_{\mathbf{3}}$ & 14.05 & 13.90 & 13.48 & 13.05 & 12.34 & 12.00 & 11.85 & 15.66 & $12.95 \mathrm{c} \pm 0.75$ \\
\hline $\mathbf{T}_{\mathbf{4}}$ & 14.10 & 14.00 & 13.70 & 13.34 & 13.15 & 13.00 & 12.00 & 14.89 & $13.33 \mathrm{a} \pm 0.75$ \\
\hline $\mathbf{T}_{\mathbf{5}}$ & 14.02 & 14.03 & 13.95 & 13.50 & 13.34 & 13.10 & 12.70 & 9.42 & $13.52 \mathrm{a} \pm 0.75$ \\
\hline $\mathbf{T}_{\mathbf{6}}$ & 13.80 & 13.50 & 13.35 & 13.00 & 12.78 & 12.37 & 11.80 & 14.49 & $12.94 \mathrm{c} \pm 0.75$ \\
\hline $\mathbf{T}_{\mathbf{7}}$ & 14.03 & 14.00 & 13.80 & 13.40 & 13.25 & 13.00 & 12.90 & 8.05 & $13.18 \mathrm{a} \pm 0.75$ \\
\hline $\mathbf{M}_{\mathbf{M}}$ & $13.04 \mathrm{a} \pm$ & $13.90 \mathrm{~b} \pm$ & $13.71 \mathrm{~b} \pm$ & $13.31 \mathrm{c} \pm$ & $12.99 \mathrm{~d} \pm$ & $12.49 \mathrm{e} \pm$ & $11.95 \mathrm{f} \pm$ & & \\
& 0.26 & 0.26 & 0.26 & 0.26 & 0.26 & 0.26 & 0.26 & & \\
\hline
\end{tabular}

Values having different alphabetical letters are significantly $(\mathrm{P}<0.05)$ different 
Bilal et al.

Table 7. Effect of selected chemical preservatives on the Overall Acceptability (sensory evaluated) of muskmelon cubes preserved in sucrose solution and stored at ambient temperature

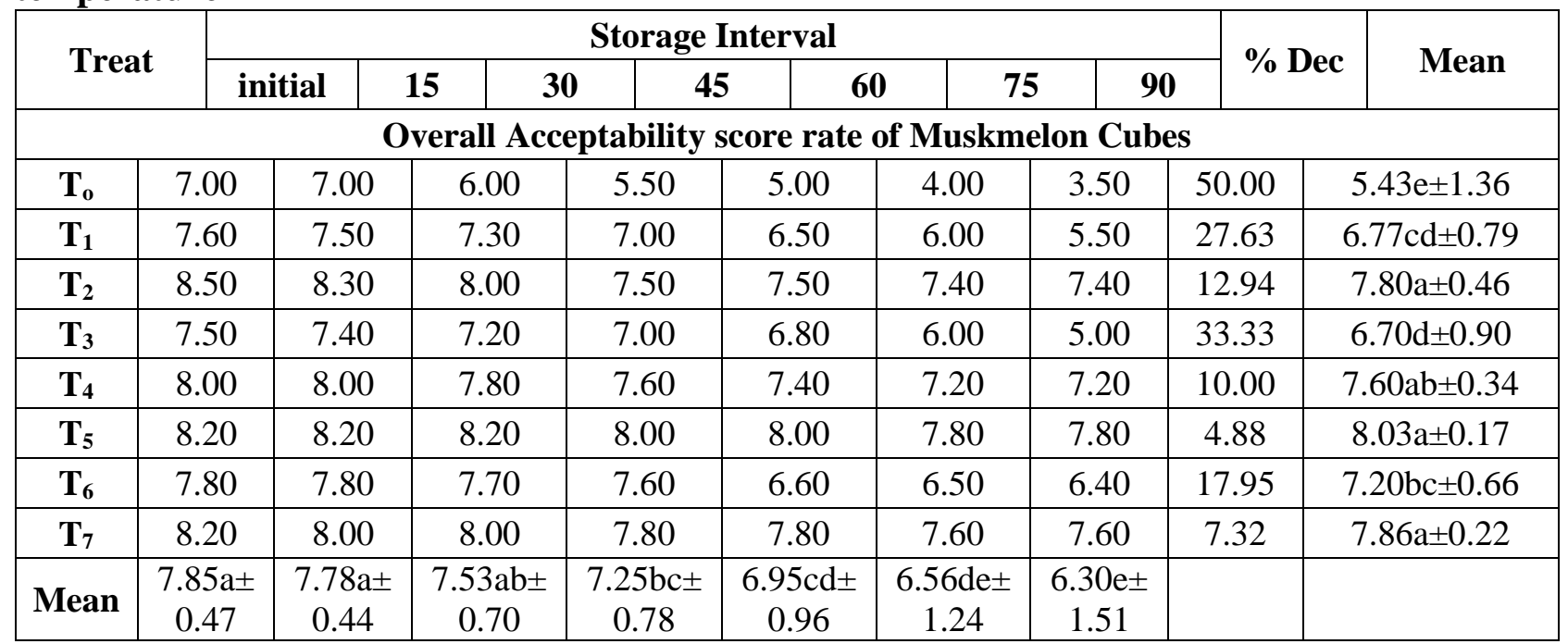

Values having different alphabetical letters are significantly $(\mathrm{P}<0.05)$ different

\section{Conclusion}

In the present research study muskmelon cubes were preserved in $30^{\circ}$ brix sucrose solution and treated with selected chemical preservatives of potassium metabisulfite and potassium sorbate with individual doses and combined doses. The samples were sealed in plastic jars and stored at room temp for ninety days. These research samples were analyzed physicochemically and organoleptically at each fifteens days of three months storage. Treatments where the muskmelon cubes were blanched and preserved with only potassium metabisulfite or combined dose of potassium metabisulfite and potassium sorbate showed best results physicochemically and organoleptically. The muskmelon cubes which were preserved with individual dose of potassium sorbate developed browning color in muskmelon cubes. Our conclusion shows that treatment $\mathrm{T}_{7}$ (muskmelon cubes which were blanched and preserved in sucrose solution with combined chemical preservatives of potassium metabisulfite and potassium sorbate) was found the best for overall quality of muskmelon preservation.

\section{Authors' contributions}

Conceived and designed the experiments: $\mathrm{H}$ Bilal \& Y Durrani, Performed the experiments: $\mathrm{H}$ Bilal, Analyzed the data: $\mathrm{H}$ Bilal, Contributed reagents/ materials/ analysis tools: YDurrani, MS Hashmi, A Muhammad, MN Din, QA Sultan, Wrote the paper: MU Din \& H Bilal.

\section{References}

1. Ahmad M (2005). Post-harvest technologies for various crops of pakistan: status quo, employment generation and prospects. Sci Tech and Devel 24(2): 33-38.

2. Lester GE (1997). Melon (Cucumismelo L.) fruit nutritional quality and health functionality. Hort Tech 7: 222-227.

3. Egbebi AO (2014). Comparative studies on the three different species melon seed; (Citrulusvulgaries, Cucumeropsis manni and Leganaria siceraria). Sky J Food Sci 3(1): 1-4.

4. Fruit, vegetables \& condiments statistics of Pakistan (2009-2010). Government of Pakistan. Ministry of Food and Agri (economic wing), Islamabad. 
5. Wedzicha BL, Rimmer YL \& Khandelwal GD (1991). Catalysis of Maillard Browning by sorbic acid. Lebensm Wiss U-Technol 24: 278-280.

6. Obanu ZA\&Ledward DA (1986). Reactivity of sorbate and glycerol in some model intermediate moisture systems. Food Chem 21(1): 57-75.

7. Roberts AC \& Mcweeny DJ (1972). The use of sulphur dioxide in the food industry. A review. J Food Technol 7: 221.

8. Kader AA (2011). Postharvest technology of horticultural crops. University of California Agri and Nutritional Resources. Pp 3529.

9. Omolo P, Tana P, Mutebi C, Okwach E, Onyango H \& Okach KO (2011). Analysis of avocado marketing in TransNzoia district, Kenya. $J$ of Develop and Agric Econo 3(7): 312-317.

10. AOAC (2012). Association of official and analytical chemists. $19^{\text {th }}$ Ed (Helrich K). Arlington, Virgina, USA.

11. Larmond E (1977). Laboratory method of sensory evaluation of food. Publication of Deptt Agri Ottawa, Canada, pp 177-183.

12. Gomez KA\& Gomez AA (1984). Statistical Procedure for Agricultural Research. $2^{\text {nd }}$ edition Pp 8-22.

13. Steel RG \&Torrie JH (1997). Principles and procedures of statistics. A biometrical approach, $2^{\text {nd }}$ ed. New York, McGraw-Hill. Pp633.

14. Fasogbon BM, Gbadamosi SO \& Taiwo KA (2013). Studies on the Osmotic Dehydration and Rehydration Characteristics of Pineapple Slices. J Food Proc Tech 4(4): 220-228.

15. Kumar SP \& Sagarandlata VR (2008). Quality of osmovac dehydrated ripe mango slices influenced by packaging material and storage temperature. $J$ Sci Industrial Res 67: 1108-1114.

16. Kumar SP \& Devi P (2011). Optimization of some process variable in mass transfer kinetics of osmotic dehydration of pineapple slices. Inter Food Res J 18: 221-238.

17. Muhammad A, Ayub M, Khaliq A \&Ullah S (2008). Microstructural changes during osmotic dehydration of parenchymatic pumpkin tissue. J Food Engg 85: 326-339.

18. Mehmood Z, Zeb A, Ayub M, Bibi N, Badshah A \& Ihsanullah (2008). Effect of pasteurization and chemical preservatives on the quality and shelf stability of apple juice. Amer J Food Tech 3(2): 147-153.

19. Wisal S, Ullah J, Zeb A\& Khan MZ (2013). Effect of refrigeration temperature, sugar concentrations and different chemicals preservatives on the storage stability of strawberry juice. Inter J Engg Tech 13(2): 160-168.

20. Zia A \& Ayub M (2012). Quality evaluation of melon cubes preserved in sweetener solution. M.Sc. Thesis. Food Sci Tech Deptt Uni Agri Peshawar.

21. Sabrina B, Renata BB, Bruna M, Petrus RR \&Trindade SF (2009). Quality and sensorial charachteristics of osmotically dehydrated mango with syrups of inverted sugar and sucrose. Sci Agric (Piracicaba, Braz) 66(1): 40-43.

22. Sacchetti G, Gianotti A \& Rosa MD (2001). Sucrose salt combine effect on mass transfer kinetic and product acceptability. Study on apple osmotic treatments. J Food Eng 49: 163-173. 